\title{
THE TRANSFER OF RADIOACTIVE MERCURY ACROSS A A MEMBRANE PRODUCED BY THE APPLICATION OF CANTHARIDES TO THE SKIN OF MAN ${ }^{1}$
}

\author{
By FRANK J. KELLY,2 ARTHUR H. SVEDBERG, AND VERNON C. HARP, JR. \\ (From the Department of Medicine, Tulane University School of Medicine and Charity Hospital \\ of Louisiana at New Orleans)
}

(Submitted for publication February 24, 1950; accepted April 10, 1950)

This report is concerned with the rate and mode of transfer of mercury across a biologic membrane. The experiments reported herein represent part of a series of studies of the pharmacologic properties of mercurial diuretics carried out in this laboratory with a mercurial diuretic (Mercuhydrin) ${ }^{3}$ labeled with radioactive mercury. ${ }^{4}$ The biologic membrane consisted of the base of a blister produced by the application of a vesicant, cantharides, to the forearm of man. It is apparent that this type of membrane is of special nature; however, it is probably more comparable to normal intact membranes of man than to isolated membranes obtained at necropsy. It is hoped that such a study of the transfer of the radiomercury of the diuretic across the blister surface might clarify some of the problems concerned with the pharmacologic properties of the diuretic.

Mercury was observed to move in both directions across this membrane in a predictable manner. Studies on confrol patients were contrasted with those on patients with cardiac disease. Certain variables were introduced to observe their effects on the transfer of mercury.

The cantharides blister, as a physiologic model, is not new, most of the earlier work having been reported in the German literature. Among the

1 Aided by a grant from the Life Insurance Medical Research Fund, a War Department Grant No. W-49-007MD-389, the Mrs. E. J. Caire Fund for Research in Heart Disease and a Public Health Service grant.

2 Life Insurance Medical Research Fund Postdoctorate Fellow (1948-1949).

3 The sodium salt of methoxy-oxymercuripropylsuccinylurea with theophylline, prepared with radiomercury in this laboratory by Messrs. Harold Krahnke, Darwin Kaestner and Edwin Sprengler through the courtesy of Dr. H. L. Daiell, Director of Research, of Lakeside Laboratories, Milwaukee.

4 Radioactive mercury $\left(\mathrm{Hg}^{203,}{ }^{208}\right)$ was obtained from the Isotopes Division of the Oak Ridge National Laboratory. many uses of the blister are those of Levaditi and Petresco (1), who in 1905 accomplished the first isolation of Spirochaeta pallida from the fluid of a cantharides blister; this was later confirmed by Gerskovic (2) and Syring (3). Others have reported the isolation of viruses, parasites, protozoa and other bacteria from the fluid of cantharides blisters. Benedek (4) suggested its use as an auxiliary blood culture method, since organisms from the blood stream commonly reach the fluid, which acts as an ideal culture medium, whereas bacteria of the skin are excluded from it. Petersen (5), by means of the cantharides blister, studied the capillary permeability of the skin vessels and relative autonomic tonus of the arterioles in various clinical conditions, and Winsor and Burch (6) used the cantharides blister to measure the rate of diffusion of water through certain layers of the epidermis. Samter (7) employed the cantharides blister to study the eosinophile counts in various allergic states and in normal subjects, as well as to study the blister fluid with regard to eosinophile response following injection of histamine, ragweed extract, and other substances into cantharides blisters.

The blister consists of serum loculations in the stratum spinosum of the epidermis near the basal cell layer. The blister fluid is separated from the skin surface by most of the stratum spinosum, the stratum granulosum, lucidum, and the entire corneum. The fluid is separated from the capillary loops in the rete pegs by only three to five cell layers of the stratum spinosum and the basal cell layers. These underlying capillary loops are variably dilated, but there is little cellular reaction or other evidence of inflammation in the dermis. Sampter (7) reports the average differential cell counts for blisters as follows: polymorphonuclear leukocytes (69-82 per cent), round cells including lymphohistiocytes (18-35 per cent), 
and eosinophiles (0-11 per cent). No correlation with the differential white blood cell count has been found. Petersen and Willis (8) report the protein content of blister fluid to be approximately 68 per cent of the serum protein concentration.

\section{METHODS}

Selection of subjects. All subjects were patients on the wards of the Charity Hospital. Patients without demonstrable cutaneous lesions, cyanosis or evidence of congestive heart failure were used for controls; the clinical data of all subjects are summarized in Tables I and II.

Preparation of the membrane. Emplastrum cantharide U.S.P. was spread evenly $\left(0.7 \mathrm{gm} . / 10 \mathrm{~cm} .{ }^{2}\right)$ on a small filter paper disk $33 \mathrm{~mm}$. in diameter. This was applied to the skin of the volar surface of the forearm and held in position by adhesive tape for 16 to 20 hours. A blister which closely conformed to the size of the filter paper resulted.

The top of the blister was carefully removed with scissors and the exposed base was washed with a physiologic saline solution. A lucite cup $38 \mathrm{~mm}$. in diameter was inverted over the exposed base of the blister and was cemented by means of an inert rubber cement 5 to the intact skin immediately surrounding the edge of the blister. Through a $7 \mathrm{~mm}$. opening in the base of the cup, $10 \mathrm{cc}$. of physiologic saline solution was added. The total elapsed time from removal of the top of the blister until the saline solution was added to the cup varied between 30 and 120 seconds. In most experiments cups were placed on both forearms so that one could be used either as a control or check on the other. The subjects experienced no significant discomfort from this procedure.

53-M Trim Cement, Minnesota Mining and Manufacturing Company, St. Paul, Minnesota.

TABLE I

Clinical data of Group I study

(Intravenous Injection)

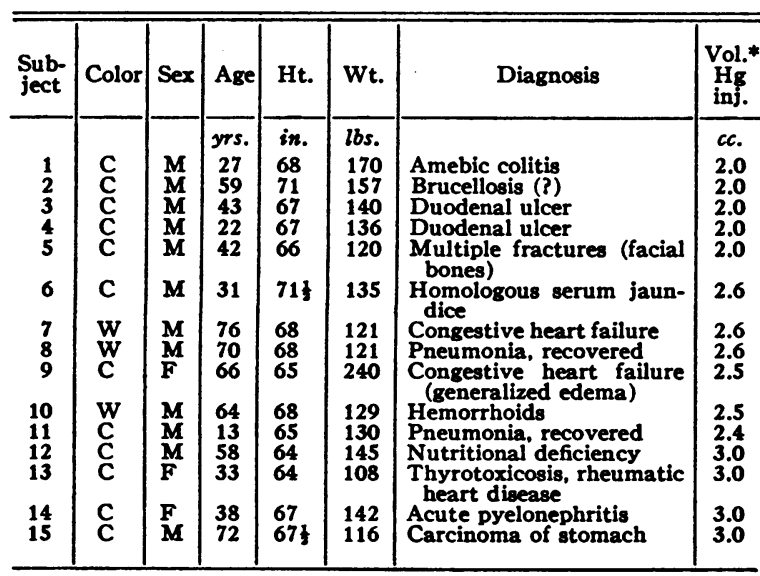

* Mercuhydrin solution.
TABLE II

Clinical data of Group II study

(Radiomercury Added to Cup)

\begin{tabular}{|c|c|c|c|c|c|c|c|}
\hline $\begin{array}{c}\text { Sub- } \\
\text { ject }\end{array}$ & Color & Sex & Age & Ht. & Wt. & Diagnosis & $\begin{array}{l}\text { Vol.* } \\
\text { Hg } \\
\text { added } \\
\text { to cup }\end{array}$ \\
\hline 16 & C & $\mathbf{M}$ & $\begin{array}{c}y r s . \\
53\end{array}$ & in. & $\begin{array}{l}\text { lbs. } \\
124\end{array}$ & Pneumonia, recovered; & 2.0 \\
\hline 17 & C & $\mathbf{F}$ & 29 & 61 & $133 \frac{1}{2}$ & Tuberculous adenitis, & 2.0 \\
\hline $\begin{array}{l}18 \\
19 \\
20\end{array}$ & $\begin{array}{l}\mathbf{W} \\
\mathbf{C}\end{array}$ & $\begin{array}{l}\mathbf{M} \\
\mathbf{M}\end{array}$ & $\begin{array}{l}18 \\
16 \\
72\end{array}$ & $\begin{array}{l}65 \\
69 \\
63\end{array}$ & $\begin{array}{l}116 \\
145 \\
121\end{array}$ & $\begin{array}{l}\text { Bronchiectasis } \\
\text { Hodgkins disease } \\
\text { Acute cholecystitis with }\end{array}$ & $\begin{array}{r}0.02 \\
.04 \\
.05\end{array}$ \\
\hline $\begin{array}{l}21 \\
22\end{array}$ & $\stackrel{C}{C}$ & $\begin{array}{l}\mathbf{M} \\
\mathbf{M}\end{array}$ & $\begin{array}{l}12 \\
42\end{array}$ & $\begin{array}{l}55 \\
69\end{array}$ & $\begin{array}{r}77 \\
141\end{array}$ & $\begin{array}{l}\text { Amebic colitis } \\
\text { Peptic ulcer; pneumonia, }\end{array}$ & $\begin{array}{l}.05 \\
.066\end{array}$ \\
\hline 23 & C & $\mathbf{M}$ & 30 & 75 & 159 & ? Peripheral neuritis; ? & .066 \\
\hline 24 & $\mathbf{W}$ & $\mathbf{M}$ & 52 & 64 & 148 & $\begin{array}{l}\text { Hypertensive heart dis- } \\
\text { ease with congestive }\end{array}$ & .076 \\
\hline 25 & $\mathbf{W}$ & $\mathbf{M}$ & 70 & 58 & 105 & $\begin{array}{l}\text { Arteriosclerotic heart dis- } \\
\text { ease with congestive } \\
\text { failure, recovered }\end{array}$ & .076 \\
\hline $\begin{array}{l}26 \\
27 \\
28\end{array}$ & $\begin{array}{l}\text { C } \\
\text { C } \\
\text { C }\end{array}$ & $\begin{array}{l}\mathbf{M} \\
\mathbf{M} \\
\mathbf{M}\end{array}$ & $\begin{array}{l}26 \\
50 \\
23\end{array}$ & $\begin{array}{l}67 \\
63 \\
68 \frac{1}{2}\end{array}$ & $\begin{array}{l}154 \\
126 \\
130\end{array}$ & $\begin{array}{l}\text { Lymphoma } \\
\text { Gastritis } \\
\text { Bleeding duodenal ulcer. }\end{array}$ & $\begin{array}{l}0.5 \\
0.5 \\
0.5\end{array}$ \\
\hline 29 & C & $\mathbf{M}$ & 42 & 68 & 220 & Pneumococcal pneumonia. & 0.5 \\
\hline 30 & C & $\mathbf{M}$ & 42 & $67 \frac{1}{3}$ & $111 \frac{1}{2}$ & $\begin{array}{l}\text { Pneumonia, recovered; } \\
\text { congestive heart failure, }\end{array}$ & 0.5 \\
\hline 31 & C & $\mathbf{M}$ & 23 & 67 & 119 & Fever of unknown origin & 0.66 \\
\hline
\end{tabular}

* Mercuhydrin solution.

Group I is comprised of Subjects 1-15 (Table I) in whom the transfer of mercury from the blood into the cup was studied. Group II is comprised of Subjects 16-31 (Table II), in whom the transfer of mercury out of the cup was studied.

Injection and sampling. Mercuhydrin labeled with radiomercury was injected intravenously in amounts varying from 2-3 cc. (accurate to 0.4 per cent), containing an activity of $19,600,000$ to $7,800,000$ counts per minute. This represents approximately 90 to 30 microcuries. Almost all of this radiomercury was recovered in the urine in one or two days. Discussion of the excretion and distribution of radiomercury administered as the mercurial diuretic, Mercuhydrin, is presented elsewhere $(9,10)$. At intervals of $10,30,60,90,120,150,180$, and 240 minutes after injection blood was drawn into a heparinized syringe from the median basilic vein of the arm not used for the injection. Simultaneously $1 \mathrm{cc}$. samples of fluid were removed from the cups. In the Group II experiments the labeled Mercuhydrin (2.0-0.02 cc. containing 4,370,000-34,000 counts per minute) was added to the physiologic saline solution in the cup instead of being administered intravenously. This represents approximately 20-0.02 microcuries, of which a mean of 24 per cent was absorbed over four hours. Presumably the excretion pattern was similar to that previously described $(9,10)$. Samples of fluid were withdrawn from the cups at identical time intervals after injection as in the Group I study.

It should be emphasized that there was no net gain or loss of fluid from the cups during the course of a 
study, when the volumes removed in sampling are taken into account.

Radioactive assay. Samples of plasma and cup fluid were prepared and dried in room air according to the method previously employed in this laboratory and described elsewhere (11-13). Studies of the method indicate that the samples can be prepared and counted within an accuracy and reproducibility of 5 per cent. No significant variations were observed in counting due to self-absorption by the different biologic fluids. All counts were expressed as counts per minute per cc., the necessary corrections being made.

\section{Experimental Procedure}

All studies were carried out at comfortable environmental temperatures $\left(22-25^{\circ}\right.$ C. $)$ with the subjects at bed rest. In addition to the control subjects two patients with progressively increasing chronic congestive cardiac failure were included in the Group I studies. Samples of edema fluid were taken simultaneously with the cup and blood samples in these two patients. Three patients recovering from chronic congestive heart failure were included in the second group. In none of these patients had a mercurial diuretic been injected within five days.

The following variations in procedure were carried out in both groups of experiments.

(1) Epinephrine (0.05 cc. of $1: 1000$ dilution) was added to the fluid in one of the cups after the collection of the 60 -minute sample.

(2) Histamine ( $0.15 \mathrm{cc}$. of $1: 100$ dilution) containing $0.015 \mathrm{mg}$. of histamine was added to one of the cups of three subjects after collection of the 60 -minute sample.

(3) Histamine was also added to both cups of one subject in Group I at the beginning of the study. To one cup $10 \mathrm{mg}$. of betadimethylamino-ethylbenzhydryl ether hydrochloride (benadryl) was added within one minute after the introduction of the histamine.

(4) Local venous congestion was produced in one subject in each group by means of a blood pressure cuff placed proximal to the cup and inflated to diastolic pressure.

\section{Calculations}

Group I experiments. As is apparent from Table I, the subjects varied considerably in body size, weight, diagnosis, and in the total quantity of isotope employed. To minimize the influence of these variables in the analysis of the data, certain calculations were made.

It was assumed that the transfer across the blister membrane was proportional to the difference in concentration of the radioactive material on the two sides of the membrane. Since mercury is not normally present in the body in any significant amount, this assumption is probably valid. It follows then that:

$$
\frac{d x}{d t}=K\left(C_{p}-C_{x}\right) \text {, }
$$

where $C_{p}=$ concentration $(\mathrm{cpm} / \mathrm{cc}$.) of radioactive mercury in the plasma,
$C_{x}=$ concentration $(\mathrm{cpm} / \mathrm{cc}$.) of radioactive mercury in the cup fluid at any time " $t$ " after injection, and

$x=$ the amount of radioactive mercury in the cup fluid,

or $\quad x=C_{z} V_{b}$,

where $V_{b}=$ the volume in cc. of fluid in the cup.

Therefore

$$
\begin{aligned}
\frac{d C_{x}}{d t} & =\frac{K}{V_{b}}\left(C_{p}-C_{x}\right) \text { or } \\
K & =\frac{\frac{d C_{x}}{d t} V_{b}}{C_{p}-C_{x}} .
\end{aligned}
$$

$\mathrm{K}$, therefore, is a constant with the dimension of $\mathrm{cc} . / \mathrm{min}$. and represents the rate of clearance of plasma perfusing the base of this membrane. In other words $K$, with reference to Group I, is the volume of plasma at the plasma concentration observed for the time interval under consideration that would have to be completely cleared of mercury per minute in order that the concentration in the cup fluid would result. $K$, as defined, was calculated from the observed data at the time intervals of 30,90 and 150 minutes after the intravenous administration of radioactive mercury.

That the above calculations are reasonable is substantiated by the fact that the solution of equation (2) in terms of $C_{x}$ results in an equation capable of predicting the concentration of radioactive mercury in the cup fluid at any given interval of time (see Discussion).

In the second group of experiments the results were calculated and represented graphically as the cumulative counts lost from the cup. Suitable arithmetic correction was made for the counts withdrawn in each sample. These values were then expressed as percentage of the total counts present at the time of the first sampling, which occurred 10 minutes after addition of mercury to the cup.

Based upon the same assumption set forth in the calculation of data from Group I, K was determined according to the equation

$$
\frac{d x}{d t}=\frac{K}{V_{b}} \cdot C_{x} \text { or } K=\frac{\frac{d x}{d t} \cdot V_{b}}{C_{x}},
$$

where $\mathrm{dx}=$ loss of radioactive mercury in percentage of that present at 10 minutes during the time interval $d t$,

$C_{x}=$ radioactive mercury in percentage present at time " $t$," and

$V_{b}=$ volume in cc. in the cup, which is $10 \mathrm{cc}$. at all times because of the aforementioned correction for sampling.

It was shown that $C_{p}$, the concentration of radioactive mercury in plasma, was zero under the circumstances of these studies.

$\mathrm{K}$ in Group II is the volume of cup fluid at the concentration observed for the time interval under consideration which would have to be cleared of mercury per minute so that the observed amount of mercury would remain. 


\section{RESULTS}

Group I. The values obtained in a representative control subject (No. 4) are presented in Figure 1 and Table III. In this experiment physio-

TABLE III

Concentration of radiomercury in plasma and cup fluid after intravenous injection

\begin{tabular}{c|c|c|c}
\hline \hline \multirow{2}{*}{$\begin{array}{c}\text { Minutes after } \\
\text { injection of } \\
\text { radiomercury }\end{array}$} & \multicolumn{3}{|c}{ Concentration of radioactive mercury } \\
\cline { 2 - 4 } & $\begin{array}{c}\text { Plasma } \\
\text { CPM/cc. }\end{array}$ & $\begin{array}{c}\text { Cup. right } \\
\text { CPM/cc. }\end{array}$ & $\begin{array}{c}\text { Cup. left } \\
\text { CPM /cc. }\end{array}$ \\
\hline 10 & 2538 & 0 & 14 \\
30 & 1717 & 36 & 60 \\
60 & 1236 & 90 & 108 \\
90 & 1008 & 138 & 154 \\
120 & 748 & 109 & 108 \\
180 & 494 & 164 & 172 \\
240 & 398 & 192 & 172 \\
\hline
\end{tabular}

logic saline was placed in the cups attached to each forearm and $16.4 \times 10^{8}$ counts of mercury in $2 \mathrm{cc}$. of Mercuhydrin was injected intravenously at " 0 " time. As can be seen, there was close agreement of the data obtained on both forearms of the same individual. The plasma regression curve was similar to those previously published from this laboratory (14).

Physiologic saline was placed in the cup on the

CONCENTRATION TIME COURSE OF RADIOMERCURY IN CUPS AFTER INTRAVENOUS INJECTION

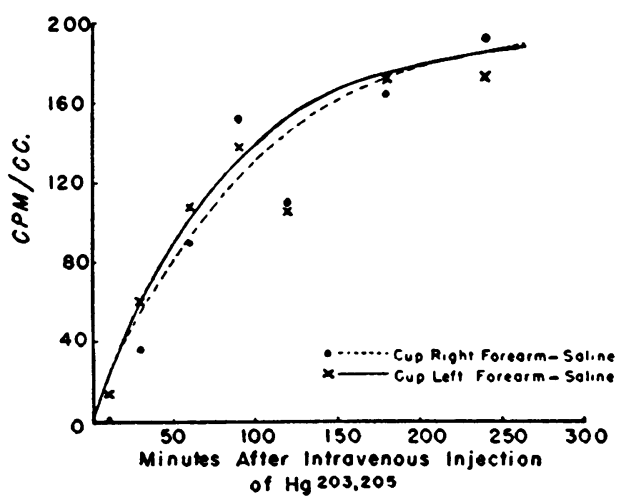

Fig. 1. Concentration-time Course of Radioactive Mercury entering into the Cup Fluid of the Right and Left Forearms of a Control Subject

Physiologic saline solution was the fluid used in both cups. Close agreement between the two curves is apparent. The reason for the deviation of the points at 120 minutes is not known.
CONGENTRATION TIME COURSE OF RADIOMERCURY IN CUPS AFTER INTRAVENOUS INJECTION

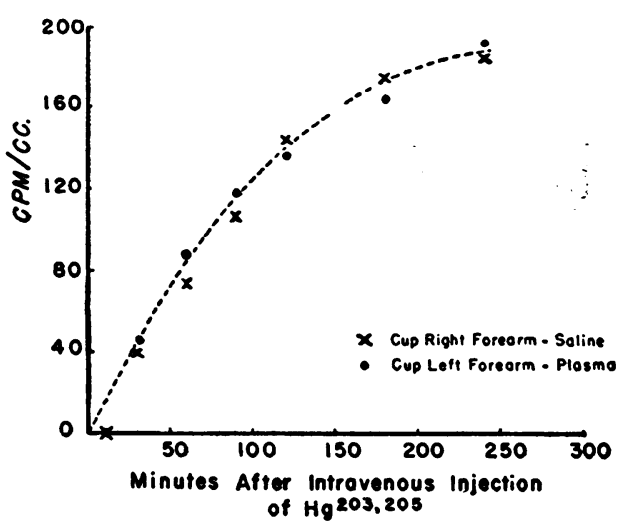

Fig. 2. The Curves Represent the Concentrationtime Course of Appearance of Radioactive Mercury in the Cup Fluid of the Right aNd Left Forearms

One cup contained a physiologic saline solution, the other the patient's heparinized plasma. Absence of any significant difference between the two curves is noted.

right forearm of Subject 6 and the same volume of the subject's heparinized plasma was placed in the cup on the left forearm. An intravenous injection of $18.4 \times 10^{6}$ counts of radioactive mercury in $2.6 \mathrm{cc}$. Mercuhydrin was made at " 0 " time. These data are presented in Figure 2 and Table IV. The plasma regression curve in this subject resembled those of other subjects. It is apparent that there is no significant difference between the concentration-time course of radioactive mercury entering into the cup containing physiologic saline and into that containing the subject's heparinized plasma.

In none of the control studies did the concentration of radioactive mercury in the cups come to

TABLE IV

Concentration of radiomercury in cup fluids (plasma and saline) after intravenous injection

\begin{tabular}{ccc}
\hline $\begin{array}{c}\text { Minutes after } \\
\text { injection of } \\
\text { radiomercury }\end{array}$ & $\begin{array}{c}\text { Concentration of radiomercury } \\
\text { Cup. saline } \\
\text { right forearm } \\
\text { CPM/cc. }\end{array}$ & $\begin{array}{c}\text { Cup, plasma } \\
\text { left forearm } \\
\text { CPM/cc. }\end{array}$ \\
\hline 10 & 0 & 0 \\
30 & 40 & 46 \\
60 & 94 & 88 \\
90 & 106 & 118 \\
120 & 144 & 136 \\
180 & 174 & 164 \\
240 & 184 & 192 \\
\hline
\end{tabular}


equilibrium with that of the plasma during the period of observation.

In Table $\mathrm{V}$ are presented the values of $\mathrm{K}$ obtained by means of Equation (2). These data were calculated from curves drawn by inspection to depict the concentration-time course of radioactive mercury in the cups and plasma. In those instances in which cups were placed on both forearms of the same individual and no significant differences were noted, the mean curve was used. The values of $K$ at 30,90 and 150 minutes after intravenous administration of the labeled Mercuhydrin were chosen arbitrarily to explore variations in the state of the membrane with time among control experiments and those into which selected variables were introduced. Considerable variation in $\mathrm{K}$ among different individuals and at different times in the same individual are also noted. This value is usually highest during the first 30 minutes and decreases progressively thereafter, indicating a progressive decline in the rate of transfer of mercury across the membrane.

TABLE V

Clearance constant for plasma perfusing membrane in Group I study after intravenous injection

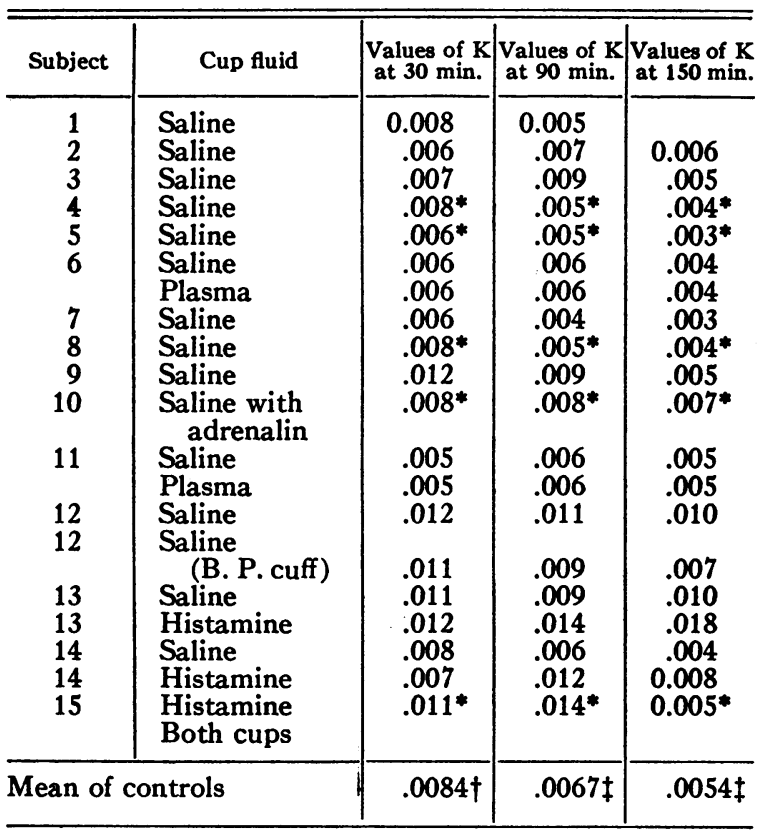

* Mean value of $\mathrm{K}$ calculated from data obtained from cups placed on both forearms of these subjects.

t All subjects included, since no variables had yet been introduced.

$\ddagger$ Subjects no. $12,13,14,15$ not included in the control group, since variables had been introduced prior to this time.
TABLE VI

Concentration of radiomercury in plasma, cup fuid and edema after intravenous injection

\begin{tabular}{|c|c|c|c|c|c|c|}
\hline \multirow{4}{*}{$\underset{\text { injection }}{\text { Min. after }}$} & \multicolumn{6}{|c|}{ Concentration of radiomercury } \\
\hline & \multicolumn{2}{|c|}{$\begin{array}{c}\text { Plasma } \\
\text { CPM/cc. }\end{array}$} & \multicolumn{2}{|c|}{$\begin{array}{l}\text { Cup fluid } \\
\text { CPM/cc. }\end{array}$} & \multicolumn{2}{|c|}{$\begin{array}{c}\text { Edema } \\
\text { CPM/cc. }\end{array}$} \\
\hline & \multicolumn{2}{|c|}{ Experiment } & \multicolumn{2}{|c|}{ Experiment } & \multicolumn{2}{|c|}{ Experiment } \\
\hline & No. 7 & No. 9 & No. 7 & No. 9 & No. 7 & No. 9 \\
\hline $\begin{array}{r}10 \\
30 \\
60 \\
90 \\
120 \\
180 \\
240\end{array}$ & $\begin{array}{r}3390 \\
2440 \\
1990 \\
1740 \\
1660 \\
1280 \\
780\end{array}$ & $\begin{array}{r}1610 \\
1110 \\
920 \\
850 \\
770 \\
630 \\
500\end{array}$ & $\begin{array}{r}0 \\
44 \\
52 \\
148 \\
168 \\
216 \\
252\end{array}$ & $\begin{array}{r}8 \\
44 \\
68 \\
112 \\
158 \\
196 \\
218\end{array}$ & $\begin{array}{r}0 \\
0 \\
0 \\
96 \\
96 \\
100 \\
120\end{array}$ & $\begin{array}{r}0 \\
0 \\
0 \\
14 \\
14 \\
30 \\
44\end{array}$ \\
\hline
\end{tabular}

In the patients with progressively increasing chronic congestive heart failure who had not received mercurial diuretics for several days (Subjects 7 and 9, Table I), values of $K$ (Table V) differed from each other considerably but fell

\section{CONCENTRATION TIME COURSE OF RADIOMERCURY IN CUPS AFTER INTRAVENOUS INJECTION}

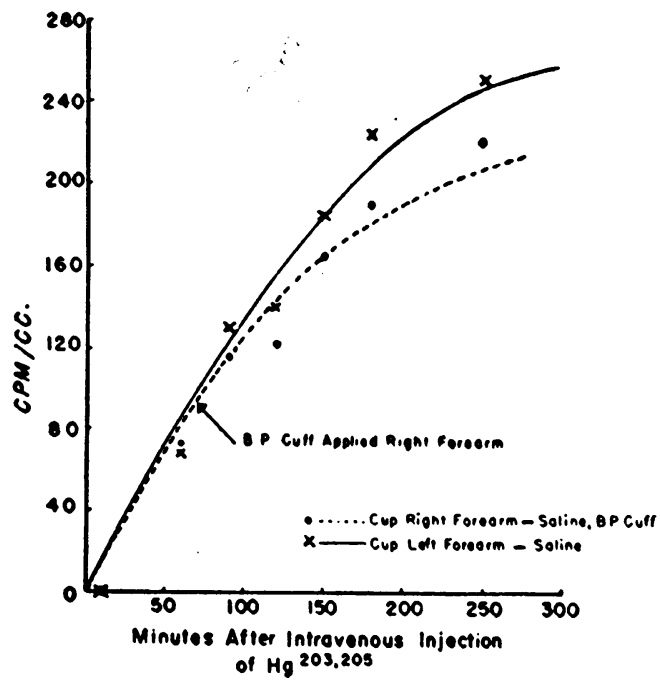

Fig. 3. Concentration-time Course of Radioactive Mercury in the Cup Fluid of the Right and Left FOREARMS

Both cups contained a physiologic saline solution. After withdrawal of the 60 minute sample, a blood pressure cuff was applied to the right arm and maintained at diastolic pressure throughout the study. The concentration-time curve for the cup of the congested arm is seen to be lower than that for the control. 
within the range of the controls. Table VI indicates the concentration of radioactivity in the samples of plasma, cup fluid and edema fluid taken simultaneously at the times indicated. If allowance is made for the differences in plasma concentration, mercury passed into the cup at a considerably greater rate for Subject 9 than for Subject 7. This leads to a value of $K$ for Subject 9 approximately twice that for Subject 7 (Table V).

Edema fluid, on the other hand, showed a relatively greater concentration of radioactive mercury in Subject 7, when allowance for differences in the plasma concentration are made. However, it is important to remember that a small amount of contamination of edema fluid by blood resulting from injury to small vessels in the process of sampling would alter the concentration of radioactive mercury considerably. Epinephrine did not influence the results.

In Subject 12 a blood pressure cuff inflated to diastolic pressure was placed on one arm proximal

\section{CONCENTRATION TIME COURSE OF RADIOMERCURY IN CUPS AFTER INTRAVENOUS INJECTION}

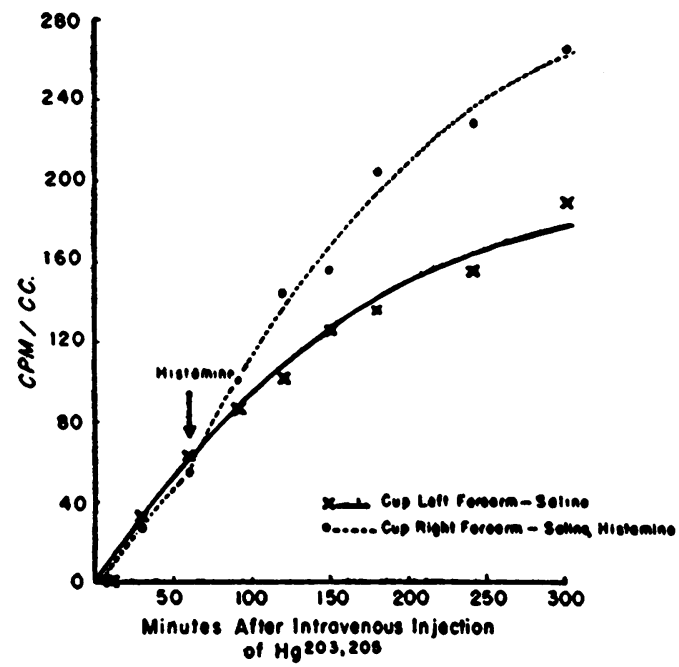

Fig. 4. Concentration-time Course of Appearance of Radioactive Mercury in the Cup Fluid of the Right AND Left Forearms

Both cups contained a physiologic saline solution. After withdrawal of the 60 minute sample, $.015 \mathrm{mg}$. histamine was placed in the cup on the right forearm, which resulted in a striking increase in rate of transfer of mercury.
TABLE VII

Clearance constant of cup fluid after addition of radiomercury in Group II study

\begin{tabular}{|c|c|c|c|c|}
\hline Subject & Cup fluid & $\begin{array}{l}\text { Values of } K \\
\text { at } 30 \mathrm{~min} .\end{array}$ & $\begin{array}{l}\text { Values of } K \\
\text { at } 90 \mathrm{~min} .\end{array}$ & $\begin{array}{l}\text { Values of } \mathrm{K} \\
\text { at } 150 \mathrm{~min} .\end{array}$ \\
\hline 16 & $\begin{array}{l}\text { Saline } \\
\text { Histamine }\end{array}$ & & .010 & .007 \\
\hline $\begin{array}{l}17 \\
17\end{array}$ & $\begin{array}{l}\text { Saline } \\
\text { Saline } \\
\text { Heparin }\end{array}$ & & $\begin{array}{l}.014 \\
.018\end{array}$ & $\begin{array}{l}.013 \\
.017\end{array}$ \\
\hline $\begin{array}{l}19 \\
20 \\
20\end{array}$ & $\begin{array}{l}\text { Saline } \\
\text { Saline } \\
\text { Saline } \\
\text { Histamine }\end{array}$ & $\begin{array}{l}.010 \\
.014 \\
.013\end{array}$ & $\begin{array}{l}.010 \\
.012 \\
.012\end{array}$ & $\begin{array}{l}.008 \\
.012 \\
.012\end{array}$ \\
\hline $\begin{array}{l}21 \\
21 \\
22 \\
23 \\
23\end{array}$ & $\begin{array}{l}\text { Saline } \\
\text { Plasma } \\
\text { Saline } \\
\text { Saline } \\
\text { Saline } \\
\text { Epinephrine }\end{array}$ & $\begin{array}{l}.015 \\
.013 \\
.011 \\
.012 \\
.013\end{array}$ & $\begin{array}{l}.013 \\
.005 \\
.011 \\
.012 \\
.013\end{array}$ & $\begin{array}{l}.009 \\
.003 \\
.009 \\
.011 \\
.012\end{array}$ \\
\hline $\begin{array}{l}24 \\
25 \\
26 \\
27 \\
27 \\
28 \\
29 \\
30 \\
31\end{array}$ & $\begin{array}{l}\text { Saline } \\
\text { Saline } \\
\text { Saline } \\
\text { Saline } \\
\text { Serum } \\
\text { Salinet } \\
\text { Salinet } \\
\text { Salinet } \\
\text { Salinet }\end{array}$ & $\begin{array}{l}.016^{*} \\
.014^{*} \\
.014 \\
.010 \\
.008 \\
.009^{*} \\
.017 \\
.017 \\
.011^{*}\end{array}$ & $\begin{array}{l}.013^{*} \\
.011^{*} \\
.011 \\
.009 \\
.007 \\
.008^{*} \\
.016 \\
.011 \\
.011^{*}\end{array}$ & $\begin{array}{l}.012^{*} \\
.010^{*} \\
.010 \\
.008 \\
.006 \\
.008^{*} \\
.014 \\
.010 \\
.010^{*}\end{array}$ \\
\hline \multicolumn{2}{|c|}{ Mean of saline controls } & .0134 & .0117 & .0104 \\
\hline
\end{tabular}

* Mean value of $\mathrm{K}$ calculated from data obtained from cups placed on both forearms of these subjects.

I In these studies nonradioactive Mercuhydrin (2.5 cc.) was injected intravenously at the beginning of each study. The data from these experiments did not differ from control data and are therefore included as controls.

to the cup 75 minutes after injection of the Mercuhydrin and allowed to remain in place until completion of the experiment. This decreased the rate of passage of mercury into this particular cup (Figure 3 ). The values of $K$ for the congested arm were uniformly lower than for the control arm (Table V).

The effect of histamine on the blister membrane was observed in Subjects 13 and 14 (Table $\mathrm{V}$ ), in whom $0.015 \mathrm{mg}$. was added to one cup 60 minutes after injection of the mercury. The transfer of mercury across the membrane (Figure 4), in both instances, was definitely enhanced, the values of $\mathrm{K}$ being twice those of the controls. A similar experiment (Subject 15) with histamine in both cups and $10 \mathrm{mg}$. of betadimethylamino-ethyl benzhydryl hydrochloride (benadryl) in one revealed that the latter had no demonstrable effect, the values of $K$ being similar to those of other histamine studies (Table V).

Group II. In this group of subjects the labeled diuretic was added to the cups and its rate of dis- 
appearance was followed. There was close agreement among different control subjects, as demonstrated by the small standard deviation of the mean points ( $\pm 1.3-2.9$ per cent) at various times after addition of radioactive mercury to the cups. The values of $\mathrm{K}$ obtained in these subjects are presented in Table VII. There was considerably less variation in the same individual at different times in this group of subjects than in Group I. Comparison of Tables V and VII reveals differences in the state of membrane behavior under the circumstances of study in Groups $I$ and $I I$ in that $K$ is uniformly higher in the second Group.

In Subjects 18, 21 and 26 the subjects' heparinized plasma was added to one cup and physiologic

\section{PERCENTAGE RADIOMERCURY REMAINING AFTER ADDITION TO CUPS}

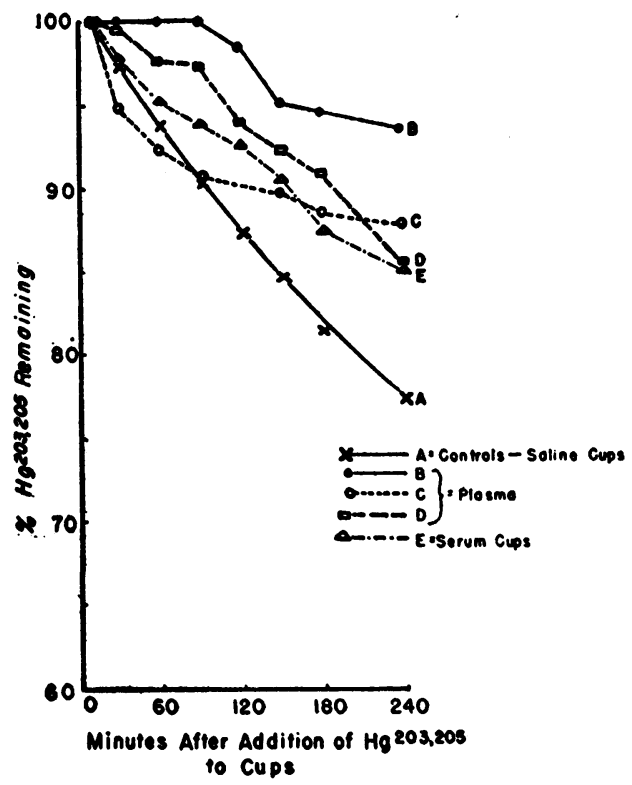

Fig. 5. Percentage of Radioactive Mercury Remaining in the Cups at Various Time Intervals AfTer ITS AdDitron

A. represents the mean of 18 control studies in which physiologic saline solution was placed in the cup.

B. C. and D. represent studies in which radioactive mercury was added to the heparinized plasma in the cups of different subjects.

E. represents a study in which the patient's serum was used in the cup. Variations in these curves are related to the differences in concentration of mercury (see text).

\section{PERCENTAGE RADIOMERCURY REMAINING AFTER ADDITION TO CUPS}

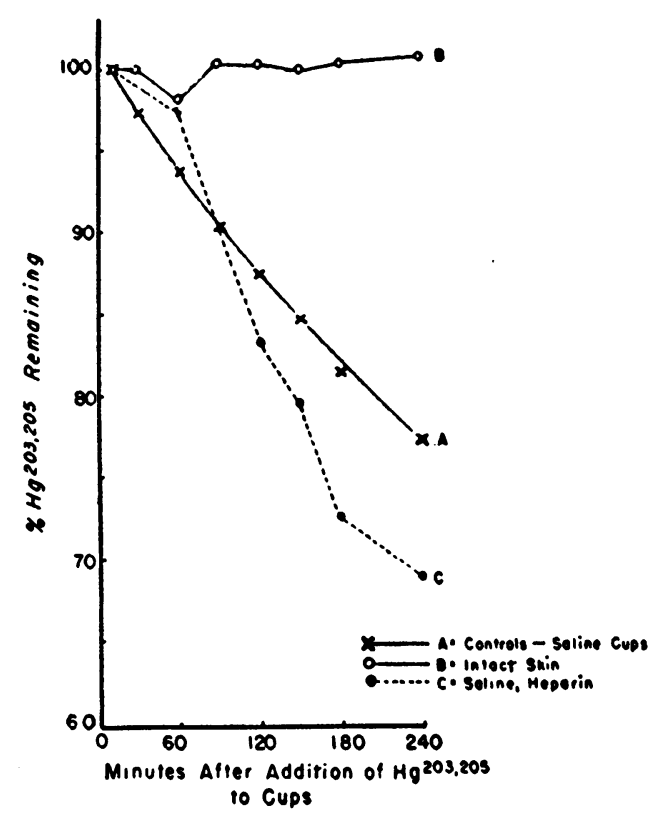

Fig. 6. Percentage of Radioactive Mercury Remaining in the Cups at Various Time Intervals AFTER its AdDition

A. represents the mean of 18 control studies in which a physiologic saline solution was placed in the cup.

B. represents a study in which the cup was applied to the intact skin of the forearm. Absence of mercury transfer is noted.

C. represents a study in which $1 \mathrm{mg}$. heparin was added to the cup; this resulted in somewhat more rapid disappearance of mercury.

saline to the other. In Subject 27, the subject's serum was used. The percentage of mercury remaining in the plasma cups at various times varied considerably among these subjects (Figure 5, B, $C, D$, and $E$ ). In each instance mercury left the cup containing plasma at a much slower rate than it did the one containing physiologic saline solution, and the values of $K$ (Table VII) were much lower than those of the controls. The final dilution of mercury in plasma or serum in these four subjects was : 1: 500 (Subject 18), 1: 210 (Subject 21), and 1: 20 (Subjects 26 and 27). Differences between the plasma curves are discussed later. The data for three patients recovering from congestive heart failure (Subjects 24, 25 and 30) did not differ significantly from the controls. 
Addition of epinephrine and histamine to the cup fluid failed to produce significant differences from control subjects, as did venous congestion. There was no demonstrable transfer of mercury through the intact skin (Figure 6, B).

Addition of heparin ( $0.1 \mathrm{cc}$. or $1 \mathrm{mg}$.) to the cup of one subject (No. 17) resulted in acceleration of the rate of disappearance of mercury from the cup (Figure 6, C). The values of $\mathrm{K}$ for this study (Table VII) were the highest observed.

In order to determine whether the presence of mercury in the plasma would influence the rate of disappearance of mercury, nonradioactive Mercuhydrin was injected intravenously (2-2.6 cc.) at the start of each of four experiments, Subjects 28, $29,30,31$ (Table II). Results of these studies did not differ from the control group and are therefore included among the latter.

\section{DISCUSSION}

Under the circumstances of these experiments, mercury traverses the membrane in both directions in a predictable manner. Based upon the assumptions: 1) that the quantity of mercury entering the cup fluid per unit of time is related to the difference in concentration of radioactive mercury between plasma and cup fluid and 2) that the plasma concentration of the radioactive mercury is given by the equation:

$$
C_{p}=C_{p 01} \cdot E^{-\alpha t}+C_{p 02} \cdot E^{-\beta t},
$$

where $C_{p}=$ plasma concentration of radioactive mercury at any time " $t$,"

$\mathrm{C}_{\mathrm{po1}}=$ that portion of the concentration of radioactive mercury in the plasma at time $t=0$, which is decreasing at the rate $\alpha$, and

$\mathrm{C}_{\mathrm{pos}}=$ that portion of the concentration of radioactive mercury in the plasma at time $t=0$, which is decreasing at the rate $\beta$,

it is possible to define the exchange across the membrane by the following equation:

$$
\begin{aligned}
C_{x}= & C_{x_{0}} E^{-\frac{K}{V_{b}-N \overline{\Delta V}} t} \\
& +\frac{C_{p_{1} 1} E^{-\alpha t_{1}}}{1-\alpha\left(V_{b}-N \overline{\Delta V}\right)}\left(E^{-\alpha t^{\prime}}-E^{-\frac{K}{\left(V_{b}-N \overline{\Delta V}\right)} t^{\prime}}\right) \\
& +\frac{C_{p_{0} 2} E^{-\beta t_{1}}}{1-\frac{\beta\left(V_{b}-N \overline{\Delta V}\right)}{K}}\left(E^{-\beta t^{\prime}}-E^{-\frac{K}{V_{b}-N \overline{\Delta V}} t^{\prime}}\right),
\end{aligned}
$$

where $C_{\boldsymbol{x}}=$ concentration of radioactive mercury in the cup"fluid at any time " $t$,"
$\mathrm{C}_{\mathrm{xo}}=$ concentration of radioactive mercury in the cup fluid at $t_{0}$,

$t_{1}=$ time from beginning of experiment to the time $\mathbf{t}^{\prime}=0$,

$\mathrm{t}=\mathrm{t}^{\prime}+\mathrm{t}_{1}$,

$V_{b}=$ initial volume of cup fluid in cubic centimeters,

$\Delta \mathrm{V}=$ volume of sample removed from the cup,

$\mathrm{N}=$ number of samples removed before $t^{\prime}=0$, and

$\mathrm{K}=$ coefficient of proportionality defined by the equation:

$$
\begin{aligned}
& \frac{d C_{x}}{d t}=\frac{K}{V_{b}-N \overline{\Delta V}}\left(C_{p}-C_{x}\right) \text { or } \\
& d_{C}\left(V_{b}-N \overline{\Delta V}\right)=\frac{d x}{d t}-K\left(C_{p}-C_{x}\right) .
\end{aligned}
$$

This latter equation is Equation (1) discussed previously under "Calculations." It must be emphasized that this equation takes into account sampling and holds only during the interval from $\mathbf{t}^{\prime}$ to the time when the next sample is taken.

From Equation (5) it is possible to predict the concentration of radioactive mercury in the cup fluid at any given time after intravenous administration. In Figure 7 are plotted the observed and theoretic concentrations of radioactive mercury in the cup fluid at the indicated times. The deviation of the observed points from the calculated curve is smaller than the errors involved in measurement. For Subject 10 the value of $K$ remained almost constant (Table V). In Subject 14 (Figure 8) the observed concentration of radioactive mercury in the cup fluid diverged from the calculated curve after 150 minutes; values of $K$ varied considerably with time. In Figures 7 and 8 the points were calculated according to Equation (5) by the use of the mean values of $K$ at 30,90 and 150 minutes in each subject. Thus, it is seen that when $K$ varied little with time, the calculated curve closely approached the observed points, whereas wide variation of $\mathrm{K}$ was associated with considerable difference between the observed points and calculated curves.

Variations in $\mathrm{K}$ among different subjects may possibly be explained by the fact that the skin of patients may differ in its response to a constant amount of cantharides. This seems probable, since white and Negro men and women of varying ages were studied. In a given individual, $\mathrm{K}$ generally decreased with time (Table V). It is our opinion that this is attributable to changes in behavior of the membrane due to healing. On the 


\section{CONCENTRATION TIME COURSE OF RADIOMERCURY IN CUPS AFTER INTRAVENOUS INJECTION}

CALCULATED CURVE AND OBSERVED POINTS

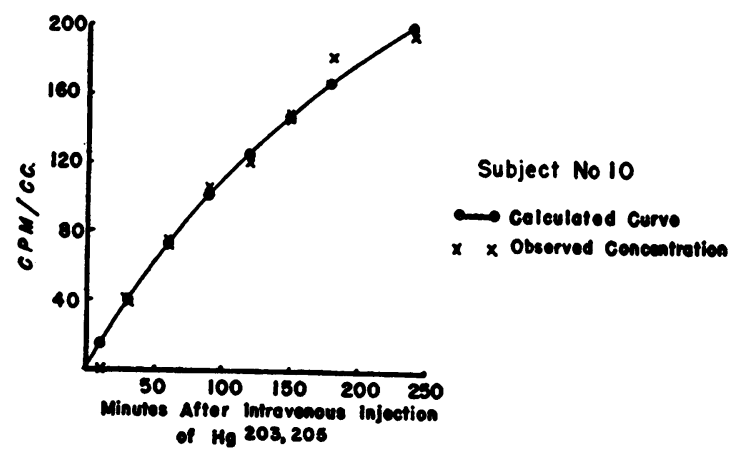

Fig. 7. Mean Concentration-time Course of Appearance of Radioactive Mercury in the Cups of Control Subject 10.

The points were calculated according to Equation (5). Close agreement between the calculated curve and the observed points is apparent.

other hand, it is noteworthy that simultaneous studies on both forearms of the same individual revealed only slight differences at any given time.

In Group II, in which mercury was placed in the cup containing a physiologic saline solution, the logarithm of the concentration of radioactive

\section{CONCENTRATION TIME COURSE OF RADIOMERCURY IN CUPS AFTER INTRAVENOUS INJECTION}

CALCULATEO CURVE AND OBSERVEO POINTS

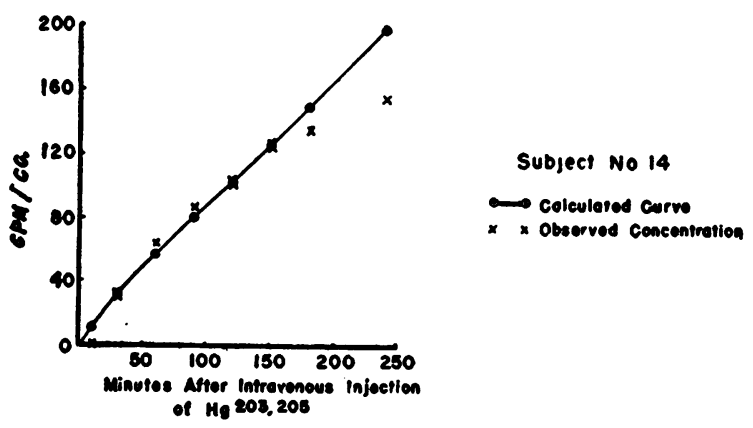

Fig. 8. Concentration-time Course of Appearance of Radioactive Mercury in the Cup of Control SubJECT 14

The points were calculated according to Equation (5). There is close conformity between the calculated curve and observed points through 150 minutes, with divergence of the observed points from the calculated curve after this time (see text). mercury plotted against time resulted in a straight line (Figure 9). In other words, a constant percentage of the radiomercury present left the cup per unit time. This phenomenon was observed over a 100 -fold range of mercury concentrations in the cup (Table II).

Substitution of plasma for saline resulted in a decrease in rate of transfer of mercury out of the

\section{SEMILOGARITHMIC PLOT OF PERCENTAGE OF RADIOMERCURY REMAINING AFTER ADOITION TO CUPS \\ GONTAOL STUDIES}

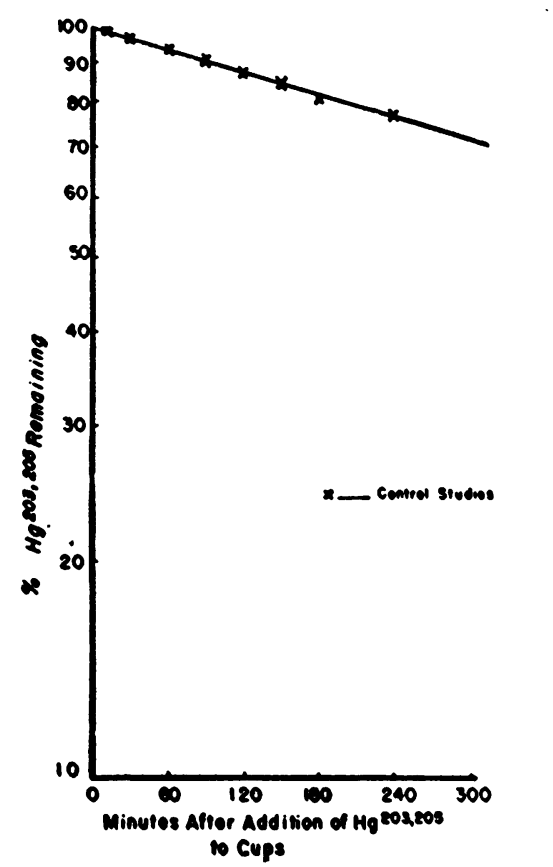

Fig. 9. Semilogarithmic Graph of the Percentage of Radioactive Mercury Remaining in the Cups at Various Time Intervals After its Addition

This represents the mean curve of 18 control studies in which a physiologic saline solution was placed in the cups (see text for discussion).

cup (Figure 5). This decrease depended on the mercury-protein ratio in the cup and therefore on the degree with which mercury was bound. Thus, it has been demonstrated in vivo that mercury in the presence of protein moves more slowly than in a physiologic solution of sodium chloride and that the rate of transfer is proportional to the dilution of mercury in plasma, i.e., to the amount of free mercury present. This offers additional support 
to the evidence of binding of mercury by protein under investigation in this laboratory. Similar studies involving isotopes of other elements are in progress.

\section{SUMMARY}

The cantharides blister provides a suitable model for the study of membrane permeability in living human subjects. Studies with the use of radioactive mercury incorporated in a mercurial diuretic were carried out with this technic. Mercury was found to traverse the membrane at the base of the blister in both directions in a predictable manner. No significant differences in transfer of mercury across the membrane were noted in patients with congestive heart failure and in control subjects. Results offer suggestive evidence of physiologically effective binding of mercury to plasma proteins.

\section{ACKNOWLEDGMENT}

The authors wish to express their appreciation to Dr. George E. Burch and $\mathrm{Mr}$. James Cronvich for their guidance and assistance during the course of these investigations and analysis of the data.

\section{BIBLIOGRAPHY}

1. Levaditi and Petresco, Cited by Benedek (4).

2. Gerskovic, L. S., Cited by Benedek (4).

3. Syring, P., Cited by Benedek (4).

4. Benedek, T., The cantharides blister and its application in microbiological research: A review of the literature and some suggestions. J. Trop. Med., $1939,42,81$.
5. Petersen, W. F., The permeability of the skin capillaries in various clinical conditions. Arch. Int. Med., 1927, 39, 19.

6. Winsor, T., and Burch, G. E., Differential roles of layers of human epigastric skin on diffusion rate of water. Arch. Int. Med., 1944, 74, 428.

7. Samter, Max, Cantharidin blister studies. J. A1lergy, 1948, 19, 225.

8. Petersen, W. F., and Willis, D. A., Capillary permeability and the inflammatory index of the skin in the normal person as determined by the blister. Arch. Int. Med., 1926, 38, 663.

9. Burch, G. E., Ray, C. T., Threefoot, S. A., Kelly, F. J., and Svedberg, A. H., The urinary excretion and biologic decay period of radiomercury labeling a mercurial diuretic in normal and diseased man. J. Clin. Invest., in press.

10. Threefoot, S. A., Burch, G. E., Ray, C. T., and Kelly, F. J., The distribution of radiomercury of a mercurial diuretic in some of the body fluids of man. Am. J. M. Sc., in press.

11. Burch, G. E., Reaser, P. B., Ray, C. T., and Threefoot, S. A., A method of preparing biologic fluids for counting of radioelements. J. Lab. \& Clin. Med., 1950, 35, 626.

12. Burch, G. E., Reaser, P. B., Threefoot, S. A., and Ray, C. T., A micropipette for preparation of samples for counting in radiobiology. J. Lab. \& Clin. Med., 1950, 35, 631.

13. Kelly, F. J., Ray, C. T., Threefoot, S. A., and Burch, G. E., The influence of self-absorption, volatilization and deliquescence in counting of radioelements. J. Lab. \& Clin. Med., 1950, 35, 606.

14. Threefoot, S. A., Ray, C. T., Burch, G. E., Cronvich, J. A., Milnor, J. P., Overman, W., and Gordon, W., Concentration-time course in the plasma of man of radiomercury introduced as a mercurial diuretic. J. Clin. Invest., 1949, 28, 661. 